\title{
Reading Lolita: A Dialogic Encounter with Self and Others
}

\author{
MICHELANN PARR, Ph.D. \\ TERRY CAMPBELL, Ph.D. \\ Nipissing University
}

\begin{abstract}
\author{
"Productive engagement," \\ to paraphrase Gadamer, \\ consists in not covering up the tension... \\ but in consciously bringing it out.
}

This paper represents a conversation between two individuals, a blending the tales of two literacy researchers: one who is interested in problems of subjectivity found in reading and in moral learning; one a researcher who is oriented toward understanding self and subjectivity with regard to the role of the researcher and underlying beliefs and assumptions about research. Bernstein (1983) tells us that "only in a dialogic encounter with what is not understood, with what is alien, with what makes a claim upon us, can we open ourselves to risking and testing our preconceptions and prejudices" (p. 195). The paper is a dialogic encounter between two individuals open to understanding, testing, and resolving the ultimate act of war within ourselves.

This paper represents a conversation between two individuals, a blending of two distinct pieces of research: one that is oriented toward investigating parallel problems of subjectivity found in reading response and in moral understanding (Campbell); one that is oriented toward understanding self and subjectivity with regard to the role of the researcher and underlying beliefs and assumptions about research (Parr).

I remember our first conversation. We both arrived at the table with different insights, understandings of the world, and perspectives despite the fact that we were both pre-service educators, engaged in the teaching of language and literacy. I was just embarking on graduate work, you had just finished your dissertation. It began quite innocently with an initial comment of how, in order to read Reading Lolita in Tehran, I found it necessary to bring a somewhat analytic stance to the reading act $-I$ had tried on numerous occasions to read this book, it truly interested me from a literary standpoint, but each time I tried to crawl inside its covers, something drew me away, and as a result, I was unable to finish. I persisted, and ultimately, it took a required assignment, one that listed this book as a potential title, to propel me through the reading. Today, I sit looking at my copy of the text, and I realize that indeed I succeeded in this task. Tabbed, labeled, and extensively noted, I am unable to part with it in its current state, as today, it represents a significant shift in thinking and perspective, a greater awareness of self, both of which ultimately lead to my growth and development as researcher. 
I remember that first conversation so well. In my dissertation (Good talk about great literature: Addressing the problem of subjectivity in moral education), I had been grappling with philosophical issues around reading and subjectivity, and there you were, right in the midst of real problems as a 'real reader reading'!

You were truly struggling with the whole subjectivity-objectivity tension not just in a theoretical way, but in your own lived experience. The timing was perfect for our conversational encounter. I had been 'addressing' problems of subjectivity, but certainly not 'solving' them, and I needed to talk to someone besides my committee!

Bernstein (1983) tells us that "only in a dialogic encounter with what is not understood, with what is alien, with what makes a claim upon us, can we open ourselves to risking and testing our preconceptions and prejudices" (p. 195). Even greater than the divide between our stages of the doctoral journey, was what we both perceived as a divide between our philosophical and moral stances toward research... a philosophical war that would require us to test our preconceptions and prejudices, likely resulting in some shifts in our thinking if we were to continue on as research colleagues and literacy teaching partners in a faculty of education.

Where you argued for subjectivity and the importance of bringing yourself to the task not only of reading but research, I felt that research could be objective. This, alone, gave us cause to resolve the conflict among, within, and between ourselves.

What is recorded here is a dialogic encounter between two individuals open to understanding, testing, and resolving the ultimate act of war within ourselves.

What we choose to read and how we respond to what we read often reflects our growing struggle and tension within ourselves, our worlds, and our relationships. Some reading experiences leave us at peace, whereas others leave us in a state of war. While it is true that any reading act can leave us at peace or at war, some, more than others, challenge us to explore our commonly held assumptions in an effort to assess and evaluate who we are and what we think we know to be true. This paper will present, in part, a struggle to determine, explore, and unearth a researcher's identity and belief system through reading response. As will become evident, this 'becoming of researcher' is far more than reading, understanding, discussing, and writing. It requires that we look inside and look beyond - inside ourselves and beyond 'mere words.' It requires that we look toward and embrace connections, relationships, and changes. It requires that we acknowledge our subjectivities and explore their role in not only our personal identities but in our relationships with others. Here I am reminded of ongoing discussions I have with my teacher candidates, particularly as they re-encounter texts from their childhood or issues that arise in new literature. I hear their reactions to words such as God, and their desire to take the easy way out (either by retreating from the literature or by substituting less contentious words) instead of challenging their own assumptions and the discomfort they feel as a result of their own identity as reader, student, and developing teacher.

Does recognizing many, varied subjectivities ("diversely acculturated souls" - Laird, 1999) complicate literary education to the point of making it seem impossible? If we ascribe to the "reader response" approach, which values the primacy of the reader's role in "evoking" a literary text (Rosenblatt, 1978), does this entail an "anything goes" approach in the literature classroom - 
one that "values" the individual response as long as it's genuinely felt? Or is there room for a "more objective" development of gradually (recursively) more refined responses achieved through re-readings, related readings, revisiting initial responses, and conversing with other readers?

Recognizing the varied subjectivities of individual mind, body, and soul need not create an impossible learning situation. Instead, individual responses can be valued in a way that allows us to step outside that which is familiar into the worlds of others who might be better positioned to help us understand and make sense of an unfamiliar world. The text I selected for review, response, and reaction with regard to researcher identity was Reading Lolita in Tehran by Azar Nafisi. Reading Lolita recounts the story of Azar Nafisi who, against the rules of the Islamic Republic of Iran, binds together the futures of seven Islamic women in the act of reading forbidden Western texts. Their reading of authors such as Jane Austen, F. Scott Fitzgerald, Henry James, and Vladimir Nabokov opened their eyes to worlds and experiences not only unfamiliar, but also immoral within the context of Islamic tradition. As each text was read, the eight women came together to discuss, to examine, and to connect what they were reading to their own lives; at times, their discussions were heated and full of anger, at other times, these conversations led to healing and liberation. Literature for many of these women became an escape from the subjectivity of their own lives and a way to find the freedom that they so desperately craved in their lives. Written as a memoir, considered as a qualitative research study, Azar Nafisi represented not only her own views, but those of her literature group as well. At times, she presented herself a full participant in the reading task, questioning and interrogating, whereas in others she adopted a more facilitative stance. Her memoir represents a subjectivity that she, in fact, grappled with throughout the novel and one that was left largely unresolved until the end. Her struggle as a writer, became my struggle as a reader; her struggle as a researcher was reflected in mine.

I am interested in your shifting perspective between third person and first person, and the fact that you characterize the struggle as "largely unresolved". This implies that the inner conflict or tension felt by you as a "real reader reading" involves your subjective realities as a "situated" reader struggling with your more cognitive perspective as a researcher, a perspective perhaps coloured by an assumption of the disembodied "absolutely objective" (impersonal, detached, impartial) researcher-as-scientist model. Do you think that part of your struggle is underscored by what Deanne Bogdan (1992) calls the "feeling, power, and location problems" of the "real reader reading" on the "subjective" side, in conflict with the image of the disembodied scientific observer on the "objective" side? [To illustrate Bogdan's concept of "feeling, power and location" problems (FPLP's): an African American or African Canadian reading the word "nigger" in a novel feels a degree of offense including deep emotional pain, a sense of lack of power over a text that uses the term without recognizing its potential effect on him/her as a reader, and is particularly vulnerable to this pain because of his/her location as a Black person.] Can you characterize any of your struggle in terms of Bogdan's FPLPs?

It is interesting that you notice this struggle. To some extent, this shift between third and first person reflects an area I have struggled with throughout the past year. Research in my previous life, as a psychology major, was objective, to be written in third person. The research writer's voice was hidden behind other researchers, couched in language that removed the subjectivity of the writer. Your observation reminds me that I am not yet done with these conflicts and 
struggles; evidently they continue to exist within my subjective reality. The title of my response, alone, characterizes my struggle: Reading Lolita: A Search for Self and Other (Author, 2004). At the time, I made direct reference to my inner struggle to understand, recognizing that this might require risk and testing of preconceptions and prejudices.

As I settled in to read, my thoughts were that research was something that I perceived as being external to myself, something I could control, something I could objectively observe. Coming from a more "objective" scientific background, I could not resolve what I perceived to be the subjective-objective, quantitative-qualitative dichotomies. This became a struggle within myself that left me unsettled with a dissonance that propelled me to seek and understand. Reading Lolita in Tehran provided me with what I considered to be a non-threatening, low-risk opportunity to explore what I perceived to be my areas of need. In my mind, I needed to resolve or come to terms with my background in order to move forward and situate myself in educational research. I recognized that it would be necessary to embark on a process of honest selfinterrogation - assessing my own personal agenda and motives - recognizing that insights garnered about could greatly affect the outcome of research (Achebe, 2002). What I did not recognize fully at the time was the power of texts to alter my philosophical and epistemological stance. Here I am not simply talking about Reading Lolita in Tehran, but many others that have surfaced into my situated reality since then, to impact and shape who I am as a researcher. I've now come to realize that research is never truly objective, and nor should it be. Far more important than objectivity is an admission of our subjectivity where we are situated fully in our research and in our writing, where the voices heard are our own, not someone else's.

I like your comment that 'the voices heard are our own' - I think the same is true when we are reading, even though the author of the text is 'someone else'. This is especially true if we espouse Rosenblatt's transactional theory of reading, where reading is experienced as a form of intense personal activity during which the reader "draws on past experience of life and language to elicit meaning from the printed words"(Rosenblatt 1970[1938], p. 26). Implicit in this whole discussion are theoretical assumptions about what reading is. It may help if I explicitly say what I think "reading" is. This is somewhat of a detour, but a needed one.

I view reading as essentially a social endeavour between reader and text and other readers, which is supported by leading theories about reading that describe the reading process as a "construction of meaning by readers" (Bogdan and Straw, 1993) ; theories that characterize reading as a "socio-psycholinguistic" interaction (Weaver 1994); and "reader-response" theory, emphasizing the "transactional" experience between the reader and the text in meaning making (Rosenblatt, 1978). I am partial to a fusion of these prominent, inter-related theories of learning as applied to literacy to form a picture of reading. I see reading as constructivist, emphasizing the reader's active role in organizing and integrating information, and as interactive in the social, psychological, and linguistic senses, emphasizing the reader's role in making meaning using both the text and prior personal knowledge. The latter theory, strongly influenced by Vygotsky (1962, 1978) and Heath (1983), focuses on the relations between thought and language and the role of social interaction in learning. Finally, I draw on reader-response theory, which grew from Rosenblatt's view of reading as a "transactional" experience: "[A] text, once it leaves its author's hands, is simply paper and ink until a reader evokes from it a literary work - sometimes, even, a literary work of art." In this approach the spotlight is on "the reader's contribution in the twoway, 'transactional' relationship with the text." (Rosenblatt, 1978, p. ix). As with the other 
theories, that which the reader brings to his/her reading in terms of life, literary, and linguistic experience, as well as the reader's present context, are fundamental in constructing, creating, or "evoking" a literary work from the printed textual message. Rosenblatt describes it nicely:

The reading of a text is an event occurring at a particular time in a particular environment at a particular moment in the life history of the reader. The transaction will involve not only the past experience but also the present state and present interests or preoccupations of the reader. This suggests the possibility that printed marks on a page may even become different linguistic symbols by virtue of transactions with different readers. Just as knowing is the process linking a knower and a known, so a poem should not be thought of as an object, an entity, but rather as an active process lived through during the relationship between a reader and a text. This experience may be the object of thought, like any other experience in life, but it should not be confused with an object in the sense of an entity existing apart from the author or reader (Rosenblatt, 1978, pp. 20-21).

Going back to your comment about the 'voices heard' being 'our own' (in the contexts of writing and research), don't you think this seems to be true for readers? This is where your view seems to intersect with an idea I have about how reading and listening are similar. This is what I wrote in my dissertation:

"The actions of the 'voice' of the reader, and the attendant activity of 'listening to oneself' as one reads, are embedded in the reading process in ways that are both literally and figuratively true. The reader's voice brings to life the inert marks on the page and lifts out the meaning or possible meanings in creative processes of construction and re-construction. While the reader is engaged in this activity, his/her background experiences in life and language frame and shape possible meanings. While the reader listens to him/herself to monitor this meaning-making, his/her eyes are firmly on the page, since the text offers to the reader both 'openness' and 'constraint' (Rosenblatt, 1978, x) in complex ways. The structure of this transaction is 'dialogical' in Bakhtin's sense, and 'conversational' in the sense of a back-and-forth interchange between speaker and listener (text and reader), with many layers of salient factors contributed by the text's language and the reader's multi-leveled cognitive, affective, and moral responses to that language. The young reader reading aloud literally listens to his/her voice speaking the words, and this activity calls up or "evokes" possible personal meanings and responses, thereby creating, bringing to life, or performing the literary work" (Campbell, 2005, pp.22-23).

I think that the mature, capable silent reader "evokes the literary work" through similar activities, even when the voice isn't literally (physically) active. I know am sometimes quite conscious of these activities as I read, particularly when reading the dialogue of characters in a novel, for instance - I "listen to myself" as I create their voices.

I agree with what you are saying. It is not simply an issue of "listening in" to conversations but often extends to visualizing the scene or event that is being described-imagining to some extent that we are there, in the text, with the other characters. By becoming part of the text, we remove the distance between self and other, often in an effort to understand the characters better, and ultimately ourselves. Going through this process makes me wonder whether it is impossible to understand ourselves without an objective stance; without this objective stance, we would remain forever trapped in our own worlds, our own subjectively created and constructed 
realities. Another unsettling question is whether it is possible to accept that understanding and situate our research without presenting to the world a necessary subjectivity that alerts others to who we are and what we believe.

The tension you highlight between "subjective" and "objective" stances often surfaces in the literature classroom. Your struggle to come to terms with the realities of your subjective self in light of your lingering image of the "objective" researcher is reflected in my own and my students' struggles with this question: How can we acknowledge and value the priority of the "subjectively" experienced engaged reading response and at the same time recognize that literary awareness requires paying attention to the development of a more "objective" critical response to the text, which is perhaps, though not necessarily, more detached? Just as you have used further reading as a powerful means of altering your "philosophical and epistemological" stance, I have found that through literature discussion groups, both further reading and talking together about personal responses promotes deeper literary and self-awareness, which is, paradoxically, "more objective" is it not? In addition, I see your process of "honest self-interrogation" as similar to the self-scrutiny of the literature student as real reader reading.

Is it paradoxically "more objective" or might we argue that honest self-interrogation and selfscrutiny leads us to a more informed awareness of our subjective realities? As a reader and as a researcher, I grew by leaps and bounds but this was not without calculated and accepted risk to what I had accepted to be true for so long. Throughout my interrogation and self-scrutiny though, I accepted that

understanding, like action, always remains a risk and never leaves room for the simple application of a general knowledge of rules to the statements or texts to be understood. Furthermore where it is successful, understanding means a growth in inner awareness, which as a new experience enters into the texture of our own mental experience. Understanding is an adventure and, like any other adventure is dangerous... But... [i]t is capable of contributing in a special way to the broadening of our human experiences, our self-knowledge, and our horizon, for everything understanding mediates is mediated along with ourselves (Gadamer,1981, pp. 109-110).

From both a reader perspective and a researcher perspective, I feel that I truly have journeyed with Azar. By sharing her dreams, hearing her frustrations, experiencing her fears, and delighting in her successes, I have come to understand my own. As a reader, I understand her motives and assumptions, I hear her voice, her perspective, her beliefs, and her personhood. This reading experience has changed who I am as a researcher. Her words are now reflected in my beliefs:

To have a whole life, one must have the possibility of publicly shaping and expressing private worlds, dreams, thoughts, and desires, of constantly having access to a dialogue between the public and private worlds. How else do we know that we have existed, felt, desired, hated, feared? 
We speak of facts, yet facts exist only partially to us if they are not repeated and recreated through emotions, thoughts, and feelings. To me it seemed as if we had not really existed, or only half existed, because we could not imaginatively realize ourselves and communicate to the world, because we had used works of imagination to serve as handmaidens to some political ploy. (Nafisi, 2003, p. 339)

Your comment about entering into your reading of Lolita aware of what you call the "calculated and accepted risk" to your personal belief system makes me think of some important connections. There are different kinds of risks we take as readers. In the case of Azar Nafisi and her students there was the basic risk of physical danger because of the severe censorship of a repressive regime. Any time we read a powerful piece of literature and really identify with a character, as you did with Azar, we risk unleashing potent emotions, which may or may not be experienced as pleasurable. (I remember sobbing uncontrollably as a teenager when I read that Sydney Carton's head had become "Number 23" when he was executed by guillotine at the end of A Tale of Two Cities, for example). Reading this book was a touchstone experience that I revisited in the final stages of my dissertation. Your risk was a calculated one; what of those vulnerable readers who are unaware and unprepared for potential upheaval?

Two years ago my pre-service teachers engaged in reading and discussing a coming-of-age novel for adolescents, called Journey, by Patricia McLaughlin. I didn't discover until well into the exercise that two of the students found the reading extremely painful because of similarities between their own difficult lives and that of the main character, Journey, who never knew his father and whose mother left him to be raised by grandparents. One student told me in person he simply could not continue reading, and the other finished the reading, but wrote extensively, in a very personal way in his journal, articulating all sorts of "feeling, power, and location" problems. Similar risks to our emotional and social well-being exist when we "go public" and share our thoughts and feelings in discussion groups.

Here I am remembering a young First Nations student I taught several years ago in Grade six. Unlike some of her peers, she was an avid reader who expressed strong emotional responses to literature, but who was gradually "silenced" by her group who viewed reading as "uncool" and "being smart in school" as "showing off." She had to go underground, and limited her responses to a written journal - an outcome that bothers me to this day. These are the sorts of experiences Gadamer refers to as "being pulled up short" and they started me on the road to thinking about readers' subjectivities and how to better understand the conditions that create those subjective experiences. That is when I began to see them as fundamentally moral endeavours.

The conditions that create these subjective experiences, as adult readers, are often within our control; not so with our students. But even with adult readers, particularly those in process of becoming teachers, we have to balance the 'risky' reading opportunities with those that might be considered a little safe... or should I say that we need to create safe opportunities to explore risky subjects. Here we have to allow readers to plan, to explore the subjectivities that make them react to words, characters, and events in texts. We need to encourage them to set goals as readers and we also need to free them to make their own decisions... they do not have to like it, but they have to consider it. I talk to my students about the goals I set and I also talk about the struggles I face as a reader. For example, a few summers ago, I recall making a conscious decision to read everyday and try to get caught up on the literature that I had so missed, that I 
had not prioritized high on my list. I recall purchasing two or three novels and making a commitment that I was going to read at least one novel per month by the end of the summer.

I began reading Reading Lolita in Tehran in June; I think I was about a quarter of the way through before I heard the voice in my head saying, "As a reader, you have choices. If you do not like the book, you do not need to finish it." This is advice that I consistently give my teacher candidates and students, but I could not resolve the moral dilemma of putting another author's work away. I had purchased the book, I had made a commitment to read the book, and I felt I should finish it, but I could not. As a reader, I recognized that some of my apprehension in completing the novel had much to do with the stance from which I was reading it. I was questioning everything she said and did, finding controversy within what she was telling her students and what she was willing to follow through on in her own life. It was when I finally articulated this conundrum that I realized that I was doing exactly what Azar was doing. I realized that in order to avoid what I would consider a hypocritical stance, I needed to follow through with what I told my students. I, therefore, put the book away... until September when I began a qualitative research course. One of the options was to read a novel that was considered to be a qualitative case study. Reading Lolita in Tehran fit this bill. I was elated! What I had begun as an aesthetic endeavour, which of course it did not turn out to be, could in fact be used as an efferent experience, something that I could, indeed, deal with (Rosenblatt, 1994). I picked up the book mid-way through September and by October 15 had finished the book, although a different person than when I had started. Is this not what reading is all about? Is this not what we aim for with our students.

I realized throughout my reading that Reading Lolita enabled me to take a somewhat objective, critical stance - yet another moral dilemma. Who was I to critique another's work especially when I did not fully understand the perspective from which it was written? How was I to resolve the dichotomy of self and other as I was reading? As I continued reading, I found myself reading through my lens of "scientific objectivity" but also found myself gradually acknowledging that there really was no such thing as true objectivity. Our lives are a reflection of who we are; what we choose to research is a reflection of who we are. A great awakening it was for me, to say that scientific objectivity only exists within our personal subjectivities, and then to acknowledge that I, as a researcher, had a right to be present in my research, in much the same way that a reader has a right to be present in the reading experience. Within my exploration, I remember writing:

Was it enough - reasonable - realistic - valid - to study others in order to gain an understanding of self which in turn might lead to a better understanding of others and therefore a better understanding of self? This was a tough one for me... I thought my research stance was predominantly objective - as researchers, we were not 'supposed to' unduly influence our 'subjects'; we were to remain objective, unattached, uninvolved; we were not to overtly impact the research experience; we were supposed to control variables and make sure that everyone had the same treatment (Parr, 2004, p. 5).

I found myself frustrated at times, because I could not figure out why there were so many, what I perceived to be, tangents, diversions, and distractions in her writing and thoughts. I was taught to keep writing concise and precise, to form hypotheses, analyze, conclude, and cite supporting evidence. Rich narratives and stories did not fall into a rather analytic and scientific description of facts... the cold, hard facts were emphasized. It was 
not until I realized that this was her way of figuring it out, of discovering who she was, that it began to make sense, and I realized that to some extent, this was similar to how I often I work through challenges and problems in both my personal and professional life, despite the fact that I would not necessarily have considered it worth writing about from a research perspective. I also realized that she needed to work through her understandings in a public space and dialogue with others in order to have it truly exist; it was not enough for her to engage in the internal, personal soul-searching, but she needed the interaction externally and the world to validate her own belief systems (Parr, 2004, p. 2).

I think you have very clearly made explicit how these struggles amount to fundamentally moral endeavours: our experiences when reading, researching, and reflecting on how our own subjectivities create complex conditions for these practices. Coming to terms with this, in an honest way in our own case, and in an open-minded way in the case of others, is very much an ongoing moral struggle. But notice how we have, each in our own way, suggested pathways and various means of finding our way through these struggles and inner conflicts. You have used an intense form of reading and a piece of rich literature to explore and scrutinize your own battle between the facts of your subjective self, and your former view of the scientifically objective self - a journey you end up describing in terms of "working through" using "dialogue with others". I have described similar processes for orchestrating the so-called "objectivity-subjectivity" dichotomy: it is possible to deepen our awareness of how subjectivity plays an integral role in reading, despite the demands for critically objective interpretations of texts. Through further reading and conversing with other readers, the personal reading response can become harmonized with a "more objective" perspective.

I have always believed that true learning comes from some sense of dissonance, or struggle within ourselves. Without this motivation, there would be no reason to investigate, to dialogue, to find our way. Some struggles are more intense than others, some require more conscious attention, some are incidental along the way. Regardless of what type of struggle we are engaged in, one thing remains true, we emerge from the struggle different people influenced by our own inner dialogue and dialogue with others.

Speaking of "struggles" have you noticed how our initial "war-like" metaphors -words such as 'struggle', 'conflict', 'tension', 'challenge', and 'dissonance' have gradually shifted? By the end of our conversation we were emphasizing 'listening', 'dialogue', 'conversing', 'orchestrating', and 'harmonizing'? Could this have been unconsciously intentional on our parts? Or perhaps the pragmatic outcome of the very process of engaging in this conversation or dialogue?

These are tough questions - ones that do not really have a clear cut answer. I would argue that the very act of dialoguing and sharing our innermost struggles with others, is, in fact, an act of harmonizing. Was it conscious? Yes. Was it intentional? Yes. Was the use of language intentional? I'm going to say no, not on my part. I was not consciously aware of the shift of language that resulted from the collaborative sense-making in which we were engaged. From my perspective, in this type of process, as readers, we share our thoughts, our ideas, and our struggles in an effort to relate to others, find congruence, and reduce the dissonance that leaves 
us in a state of war.

When we began this paper with the metaphor of war, we wondered whether we could consciously keep the language of war out of our dialogue. Looking back, it is obvious that we could not. It was and is ingrained into who we are and represents well our process as readers. We began, to some extent as individuals, each with our own view of the world and view of the reading process. We finish, with a more harmonized world view, one that recognizes that peace within oneself is the ultimate act of reading, not war. I wonder though, without the metaphor of war, whether peace would ever be attainable. Perhaps real readers reading: acts of war within ourselves is a necessary precursor to real readers reading: in perfect harmony.

Our final comment, a harmonized comment, takes the form of a found poem that represents fully our process and brings us full circle:

real readers reading: acts of war within ourselves covering up the tension growing struggle and tension within ourselves, our worlds, and our relationships. struggle vulnerable risk_prejudices control

largely unresolved conflict or tension_emotional pain_lack of power unsettled dissonance calculated and accepted risk

a great awakening choices - moral endeavours - shifting perspectives seek and understand non-threatening, low-risk

openness - voices heard - listening to oneself - share our thoughts and feelings social endeavour - fusion - honest real readers reading: in perfect harmony 


\section{References}

Achebe, N. (2002). Getting to the source: Nwando Achebe - Daughter, wife, and guest - A researcher of the crossroads. Journal of Women's History, 14(3): 9-31.

Bakhtin, M.M. (1986). Response to a question from the Novy Mir Editorial Staff. In Speech genres and other essays, (pp. 1-9). Trans. V. W. McGee. E. C. Emerson \& M. Holquist. Austin: University of Texas Press, 1986. 1-7.

Bernstein, R.J. (1983). Beyond objectivism and relativism: Science, hermeneutics, and praxis. Philadelphia: University of Philadelphia Press.

Bogdan, D. (1992). Re-Educating the Imagination: Toward a Poetics, Politics, and Pedagogy of Literary Engagement. Portsmouth, NH: Heinemann.

Bogdan, D. and Straw, S. (Eds.). (1993). Constructive Reading: Teaching Beyond Communication. Portsmouth NH: Boynton/Cook.

Campbell, T. (2005). Good Talk About Great Literature: Addressing the Problem of Subjectivity in Moral Education. Unpublished PhD dissertation, University of Toronto.

Dickens, C. (1950 [1859] A Tale of Two Cities. Modern Library of the World's Best Books.

Gadamer, H.-G. (1981). Reason in the age of science (F.G. Lawrence, Trans.) Cambridge, MA: MIT Press.

Heath, S. B. (1983). Ways with words: Language, life, and work in communities and classrooms. New York, NY: Cambridge University Press.

Laird, (1999). Recapitulating? Philosophy of Education. Urbana, Ill.: University of Illinois.

Nafisi, A. (2003). Reading Lolita in Tehran. Toronto, ON: Random House Canada.

Parr, M. (2004). Reading Lolita: A search for self and other. Unpublished manuscript.

Rosenblatt, L. (1978). The reader, the text, the poem: The transactional theory of the literary work. Carbondale and Edwardsville: Southern Illinois University Press.

Rosenblatt, L.M. (1994). The transactional theory of reading and writing. In R.B. Ruddell \& N. J. Unrau (Eds.), Theoretical models and processes of reading ( $5^{\text {th }}$ Ed.) (pp. 1363-1398). Newark, DE: International Reading Association.

University of Notre Dame.

Vygotsky, L. S. (1962). Thought and Language. Cambridge, MAS: The M.I.T. Press.

Vygotsky, L. S. (1978). Mind in Society. Cambridge, MA: Harvard University Press.

Weaver, C. (1994). Reading Process and Practice: from socio-psycholinguistics to whole language. Portsmouth, NH: Heinemann.

\section{Author Biographies}

\section{Dr. Terry A. Campbell}

Terry Campbell was educated at the University of Toronto, where she received a Hon. B.A., M.A., and Ph.D. on "Good Talk About Great Literature:

Addressing the Problem of Subjectivity in Moral Education." She also completed a B.Ed. at Nipissing University, where she teaches in the Faculty of Education specializing in language arts, literacy, drama, and kindergarten. 
Dr. Michelann Parr

Michelann Parr completed her Hon. B.A., B.Ed., and M.Ed. at Nipissing

University in North Bay Ontario and her Ph.D. at McGill University in

Montreal, Quebec. Her research interests focus on the use of text-to-speech

technology with students, teacher development, and literacy. She is currently associate professor in the Faculty of Education at Nipissing University where she specializes in language arts, literacy, drama, and special education. 